\title{
Financial-Economic problems of innovative agricultural development in Russia
}

\author{
$V . V$. Ilyashenko* \\ Ural State University of Economics, 620144 Ekaterinburg, Russia
}

\begin{abstract}
The article discusses the economic problems of the innovative development of agriculture in the Russian Federation. The author describes the features of this process in agriculture that impede the introduction of innovations. As a result, the problems of innovative development that are characteristic of the economy as a whole under the specific conditions of agricultural production are intensified. Analyzing statistics, the author shows that the import substitution policy in agriculture in Russia is not fully implemented. The article describes the interconnection of the innovation process with the development and implementation of research and development and investment activity in the industry. The article analyzes the problems of using both own and attracted financial resources for innovative development. The author shows the problem of disparity in prices for agricultural and industrial products. The article also underlines the relationship of innovation and investment in human capital, the formation of human resources. The author makes the conclusions and proposals to stimulate the innovative development of agriculture.
\end{abstract}

\section{Introduction}

One of the main tasks of the development of the national economy is to ensure innovative development. Its solution is impossible without creating a stimulating economic mechanism aimed at creating the conditions for the development of innovations and their implementation in production. At the same time, it is necessary to take into account the features of the innovative development of agriculture related to the specifics of this industry and the agribusiness as a whole. They cause additional difficulties in achieving innovative development of agricultural production and ensuring food security of the country.

\section{Materials and methods}

When analyzing the economic problems of innovative development, we used scientific articles devoted to this topic, as well as statistical materials of Rosstat. In writing the article we applied comparison methods, groupings of indicators, expert estimates, index method, etc.

\footnotetext{
*Corresponding author: k-45409@planet-a.ru
} 


\section{Results and discussion}

The need for innovative development of agriculture is primarily due to the level of its modern economic and technological development. According to Rosstat, the share of crop production and animal husbandry in gross value added, after the imposition of sanctions against Russia, increased from $3.5 \%$ in 2014 to $3.9 \%$ in 2015. This share decreased in subsequent years, and in 2018 amounted to $3.2 \%$, i.e. was lower than in 2014 . Thus, even significant Western measures to restrict agricultural exports to the Russian Federation did not fully lead to the implementation of the import substitution policy in our country, which was set as one of the main tasks of the economic development in recent years. According to Rosstat, the coefficient of renewal of fixed assets in crop production and animal husbandry for the period at the end of 2014 and 2018 decreased from $14.3 \%$ to $12.9 \%$, and the level of depreciation of fixed assets increased from $39.0 \%$ to $41.8 \%$.

The relevance of the innovative development of agriculture is reflected in scientific works devoted to this problem. In the article, Altukhov A.I. distinguishes the main reasons that hinder the transition of agriculture to an innovative development model. In his opinion, the agricultural economy is such that it hampers not only expansion, but simple reproduction. Innovation is limited and is available only to large agricultural producers. The author identifies three main areas of innovative development of agriculture: innovation in the human factor, innovation in the biological factor, technological innovation. The author proposes economic and organizational measures to stimulate innovation [2]. Anikin P.V. and Frolova N.D.in their work identify factors that characterize the innovation activity of the regions and consider four groups of indicators for assessing innovation. The authors describe the specifics of innovative processes in the agricultural sector and the need to take into account the requirements of both economic laws and the laws of nature. The authors consider that an important reason for restraining innovation processes is the lack of competitive national agricultural machinery and the use of largely imported equipment, as well as the lack of efficiency of the organizational and economic mechanism for the development of innovations [1]. Maslova V., Zaruk N., Avdeeva M. connect the development of innovative processes with increased investment activity. The authors think that one of the main factors restraining the development of agriculture is the low level of accumulation in this industry. The problem of financing investments depends on three main components: profitability of producers, the possibility of obtaining credit resources, and macroeconomic stabilization of the economy. The authors consider digitalization of agriculture to be one of the important directions of enhancing innovation [9]. According to A.I. Bogachev, the level of agricultural production in Russia is carried out in accordance with the third-fourth technological regimes, while the leading agricultural economies of the world are based on the sixth technological regime associated with innovations in the field of nanotechnology, biotechnology, alternative energy and new information technologies. The author characterizes the features of innovative processes in agricultural production. He associates low innovation activity with an ineffective mechanism for mastering innovation in agriculture. There is a higher demand for new technologies from large and medium-sized agricultural enterprises [6]. Kozlov V. believes that the main obstacle to innovation in agriculture is the imperfection of the institutional environment. He notes the significant dependence of Russian agricultural producers on foreign suppliers of better quality machinery, seeds and other components of agricultural production. The author pays special attention to the development of information and advisory services that contribute to the intensification of innovation [8]. Yangiboev Kh.B. considered features of innovation processes in agriculture and the main directions of innovation policy in the agricultural sector [14]. 
Analysis of the economic problems of the innovative development of agriculture is associated with the determination of its features not only in this industry, but also in other sectors of the agribusiness that process and sell agricultural products. The most significant features include the following:

- a significant dependence of products on natural and climatic conditions;

- the relationship of technological and natural processes, which means the contradictory nature of their mutual use;

- Agriculture is the oldest branch of the economy associated with the production of products using traditional technology, the change of which does not always contribute to better meeting the needs of the population in terms of its consumer qualities;

- the needs of people in agricultural products and products of their processing to a certain extent are sufficiently stable, and therefore new products may be perceived with distrust;

- the relatively small scale of production within one agricultural enterprise, due to their significant territorial isolation;

- a significant duration of the production cycle of agricultural products;

- insufficient qualifications of agricultural workers in the field of innovation

- lack of modern progressive organizational and economic forms of interconnection of scientific and industrial organizations in agriculture;

- financial situation, not stable enough, and low profitability of many agricultural commodity producers.

As a result of the above features, the problems of the development of innovative activity in the national economy are intensified in agriculture and agribusiness as a whole. According to Rosstat, the share of innovative goods, works, services in the total volume of goods shipped, work performed, and services decreased from $9.2 \%$ in 2013 to $6.5 \%$ in 2018 in the Russian Federation. In 2016, the proportion of organizations implementing technological, organizational, marketing innovations as a whole was $8.4 \%$, in crop production it was only $4.2 \%$, and in animal husbandry $-4.7 \%$. These indicators are the lowest in comparison with other types of economic activity. The costs of technological innovations in the Russian Federation on the whole amounted to 1.4 trillion rubles in 2017, in agriculture the costs amounted to 14.8 billion rubles, i.e. only $1.4 \%$ of the total cost. In the food industry, the share of these costs was at a slightly higher level -50.7 billion rubles, or $3.6 \%$ [9, p. 35].

The problems of the development of innovative activity in agriculture are to some extent related to its relatively low technological level compared to industrial production. So, Balatsky E.V. and Ekimova N.A. believe that "if the research sector offers developments of a too high level compared to existing production, the latter cannot use them effectively due to the limiting effect of the technological leap effect, which cannot be realized without the complete dismantling of the initial production base. In this regard, pioneer developments remain unclaimed by archaic production ..." [3, p. 11]. Annually up to $40-50 \%$ of completed scientific and technical developments remain unclaimed by agricultural production [2]. As the analysis of the scientific support for the agricultural sector showed, of the total number of completed, accepted, paid by the customer and recommended for implementation of applied scientific and technological developments, only $2-3 \%$ were implemented in limited volumes, $4-5 \%$ were implemented in one or two farms, and fate of $60-70 \%$ of the development was unknown in 2-3 years either by the customer, or by the developer, or by consumers of scientific and technical products. In 18 developed countries over the past three decades, the share of expenditures on agricultural research increased from 0.96 to $2.2 \%$, in Russia it decreased $[4,5]$. As noted in the Federal Scientific and Technical Program for the Development of Agriculture for 2017 - 2025, with an increase in the cost of science in Russia as a whole, the share of agricultural sciences in 
their total volume steadily declined, reaching a minimum in $2014-2015-1.6$ percent ( in 1994, it was 3.6 percent) [13]. In recent years, the situation has not improved in this regard. Thus, according to Rosstat, the costs of civil science from the federal budget in the whole country fell from $0.56 \%$ in 2009 to $0.4 \%$ in 2018 . At the same time, the share of domestic spending on research and development in agriculture, hunting, fishing and fish farming of the total cost for these purposes amounted to only $0.06 \%$ in 2017 , and to $0.03 \%$ in 2018 .

Revitalization of innovation is impossible without an increase in investment in the development of agriculture and other sectors of agribusiness. The need to develop innovative and investment activities is growing due to the reduction in the number of agricultural workers. According to Rosstat, the average annual number of people employed in crop production and animal husbandry decreased by $11.2 \%$ for the period from 2014 to 2018. The share of investments in fixed assets in Russia's gross domestic product decreased from $21.2 \%$ in 2013 to $20.0 \%$ in 2018 . For comparison, in China, it has been annually at least $36 \%$ over the past 17 years [9]. According to Rosstat, the volume index of investments in fixed assets in crop growing, animal husbandry, hunting and the provision of related services in these sectors amounted to $92.7 \%$ in $2014,87.4 \%$ in 2015 . In 2016 , it reached the maximum of $113.1 \%$, but in subsequent years it decreased significantly: in $2017-108.2 \%$ in $2018-104.1 \%$, which can negatively affect the implementation of the import substitution policy. Potekhin N.A., Potekhin V.N., Voronina Ya.V. connect the problem of investments with the fact that "the numerous federal and regional programs adopted since 2013 and currently include about fifty options for possible "targeted" investment in agriculture of individual sectors and territories." As a result, government investment does not solve the main problems and does not provide high rates of agricultural development, but is aimed at solving minor problems [11].

Innovative development involves the use of financial resources. As for the own funds of agricultural organizations, their capabilities are limited. According to Rosstat, the level of profitability by type of economic activity "crop production and animal husbandry", which significantly increased compared to the early 2000 s and reached $18.6 \%$ in $2014,21.7 \%$ in 2015. This level decreased in subsequent years and amounted to $15.4 \%$ in 2018 , and the proportion of unprofitable organizations in 2018 was $26,2 \%$. Gross income and profit of agricultural producers depend on product prices. In the Russian economy, inflationary processes have slowed down in recent years, cost inflation being decisive in modern conditions [7]. At the same time, according to Rosstat, the producer price index of agricultural products not only decreased over the period from 2015, when it was at $114.1 \%$, but also amounted to less than 100\% compared to the previous year (in $2017-97,7 \%$, in $2018-99.2 \%$ ). In crop production, in 2018, the producer price index amounted to $97.3 \%$, among them the production of grain and pulse crops - $99.1 \%$, vegetables $-94.7 \%$; in livestock $-100.1 \%$, among them livestock and poultry $-101.6 \%$, milk $-93.2 \%$. The given indicators are much lower than in industrial sectors. Thus, the producer price index of industrial goods in recent years has increased. In 2018 compared to the previous year it was at the level of $111.7 \%$, among them $120.7 \%$ in mining and $110.3 \%$ in manufacturing. The above data indicate, firstly, the disparity in prices for agricultural and industrial products; and secondly, lower financial opportunities for innovative development of agriculture in comparison with other sectors.

As a result, the share of attracted funds in investments in fixed assets in agriculture increased from $40.8 \%$ in 2015 to $47.9 \%$ in 2018 , while the share of budget funds amounted to only $2.2 \%$ in 2018 . The debt in crop production and animal husbandry owed to banks increased very significantly: at the end of 2014 it amounted to 1260.9 billion rubles, at the end of 2018 it amounted to 1692.7 billion rubles, that is, increased by $34.2 \%$. In accordance with the Federal Law of the Russian Federation N 264-FZ of December 29, 2006 "On the Development of Agriculture", subsidies are provided to the budgets of the constituent 
entities of the Russian Federation from the federal budget for the reimbursement of some of the cost of paying interest on loans received by agricultural producers. Given the importance of innovation, additional measures may be provided to subsidize loans used for this purpose. It is also advisable to introduce tax incentives for profits allocated to investments and innovations.

Innovative development of agriculture is impossible without the formation of human resources, investment in human capital. In 2018, 1,147.9 thousand people were enrolled in the bachelor's, specialty, and master's programs in the Russian Federation, among them 48.5 thousand were people in the scientific field of agriculture and agricultural sciences, i.e. only $4.2 \%$ of the total amount [10]. The quality of higher education is of great importance for the innovative development of the economy. To a large extent, it depends on the independent training of students, "the formation of knowledge and skills of a free, critical, self-learning person who is able to solve complex (interdisciplinary and interprofessional) social, environmental and economic problems" [12, p.8]. As for the graduation of skilled workers serving in subject areas and individual enlarged groups of professions in agriculture and agricultural sciences, in 2018 it amounted to 17.6 thousand people and decreased compared to 2016 (19.7 thousand people), i.e. by $10.3 \%$.

\section{Conclusion}

We can draw the following conclusions, based on the research conducted in the work:

- In the study of innovative processes in agriculture, it is necessary to take into account their features, resulting from the specifics of the industry.

- The proportion of organizations engaged in technological, organizational, marketing innovations in crop production and animal husbandry is significantly lower than in the Russian economy as a whole. The share of technological innovation costs in agriculture is very low.

- Innovative processes are interconnected with investment activities. In recent years, the growth of investment in fixed assets in crop production and animal husbandry began to decline.

- The basis of innovation is research and development. The share of agricultural sciences in the total cost of science in Russia has declined. The level of implementation of applied scientific and technological developments in production remains low.

- Due to the decrease in the level of profitability in recent years, the possibilities of using own funds of agricultural organizations for the development of innovative activity are limited. Expanding the use of borrowed funds requires the adoption of additional measures to subsidize loans for innovation and the introduction of tax benefits for profits allocated to investments and innovations.

- It is necessary to eliminate the disparity in prices for agricultural and industrial products that is currently observed.

- There are problems in the formation of the personnel potential of the industry, which plays a decisive role in the development of innovative processes.

\section{References}

1. P.V. Anikin, N.D. Frolova, Financial analytics: problems and solutions, 48 (138), 2 (2012)

2. A.I. Altukhov, Bulletin of the Oryol State Agrarian University, 6 (15), 4 (2008)

3. E.V. Balatsky, N.A. Ekimova, Manager, 10 (5), 9 (2019)

4. V.I. Belousov, A.V. Belousov, Economist, 7, 80 (2009) 
5. V.I. Belousov, A.V. Belousov, Problems of the modern economy, 2, 15 (2010)

6. A.I. Bogachev, Bulletin of the NIIEI, 5 (96), 95 (2019)

7. V.V. Ilyashenko, L.N. Kuklina, Regional Economy, 14 (4), 1370 (2018)

8. V. Kozlov, Agricultural policy: problems and solution,s 11, 15 (2019)

9. V. Maslova, N. Zaruk, M. Avdeev, AIC: economics, management, 10, 32 (2019)

10. N.V. Bondarenko, L.M. Gokhberg, N.V. Kovaleva, Education in numbers: 2019: a brief statistical digest, Nat researched University "Higher School of Economics", 96 (2019)

11. N.A. Potekhin, V.N. Potekhin, Ya.V. Voronina, Agrarian complex of the Urals, 9 (176), 91 (2018)

12. V.L. Tambovtsev, I.A. Rozhdestvenskaya, Manager, 11 (1), 2 (2020)

13. The Federal Scientific and Technical Program for the Development of Agriculture for 2017-2025, adopted by the Government of the Russian Federation on August 25, (2017)

14. H.B. Yangiboev, Innovative economy: prospects for development and improvement, 3 (13), 177 (2016) 